\title{
Practice of Narrative Teaching Method in Ideological and Political Theory Course
}

\author{
Yuanyuan Wang \\ Ideological and Political Department, Xi'an Peihua University,Xi'an, 710125, China
}

64789178@qq.com

\section{Keywords: Text narration; Image narration; Memory narration}

\begin{abstract}
Based on the theory and method of educational narrative research, the narrative teaching method of Ideological and political course is constructed. The text narration, image narration and memory narration promote the transformation of Ideological and political education narrative. It mobilizes enthusiasm and initiative in learning, strengthens the pertinence and effectiveness of classroom teaching, and enables students to accept rationally, identify emotionally and practice the results of Ideological and political education in action.

In the process of Ideological and political education, which kind of narrative way to educate students directly affects the effect of Ideological and political education. In recent years, with the development of the times and social changes, especially the wide use of new media, ideological and political education is facing the "island phenomenon", resulting in the decline of social identity of Ideological and political education narrative. In March 2017, Chen Baosheng, Minister of Education, answered reporters 'questions about the lack of affinity for ideological and political education in Colleges and universities. He also admitted that the "formula" may be old, the "craft" is rough, and the "packaging" is not so fashionable. The phenomenon of "isolated island" and its effect in Ideological and political education are not obvious, which forces the improvement of narrative language, narrative style, narrative system and narrative mode of Ideological and political education.
\end{abstract}

Constructing a narrative teaching method of Ideological and political education with text, image and memory. In the teaching of Ideological and political theory, we should improve the narrative language, narrative style, narrative system and narrative way. Enhance the popularity of Ideological and political education text narrative, ideological and political education image narrative innovation and ideological and political education memory narrative of the times. With the narrative style that students like to hear and hear and the social memory that they have deep experience, the students' identity of Ideological and political education narrative can be improved. To achieve the "speech of the Political Council". In his speech at the National Conference on Ideological and political work in Colleges and universities, General Secretary Xi Jinping stressed that "we should make good use of the main channel of classroom teaching". The ideological and political theory course should be strengthened in the course of improvement, enhance the affinity and pertinence of Ideological and political education, and meet the needs and expectations of students growth and development.

\section{Text, Image and Memory: an Overview of Ideological and Political Education}

In the 1960s, narratology as a discipline was born in France, and the independent ad systematic study of narrative activities began formally. Since the 1990s, various fields of humanities have introduced narrative into their own research framework, forming a grand prospect of "narrative turn". Educational narrative has gradually become a unique research field. Richardson, an American scholar, regards narration as a mode of reasoning and expression, which combines the unity of rationality and sensibility. He looks at the world through narration and expresses it to others at the same time. Canadian scholars Clandinin D. J. and Connelly F. M. wrote Narrative Inquiry: Experiences and Stories in Qualitative Research.

After 1990s, educational narrative research began to rise in China. Whether in theory or in practice, educational narrative has become a hot topic among scholars. Hu Yamin's narratology 
(1994) opened the first place in Chinese narrative research. Professor Ding Gang edited a series of books on Chinese educational narrative research, in which the educational narrative inquiry (2007) systematically expounds the research framework and theoretical system of educational narrative. Linde's Outline of Educational Narration (2008) explains the connotation, types and categories of educational narration. Chen Ranxing's Narrative and Ideology (2013) criticizes and constructs the ideology of narration. There are few papers on Ideological and political education in universities. In HowNet, only 28 papers can be found on the subject of "Ideological and Political Education Narrative Law". Professor WangQiang of Northwestern University applies the theory and method of educational narration to the teaching of Ideological and political theory. He put forward the narrative field of "principle class" teaching. In the Marxist narrative, the teachers of "Principles Course" should be good at creating a rigorous logical field, a changing historical field, a lively realistic field, a pluralistic dialogue field, and by their own understanding of Marxism, to impact the students' theoretical thinking, inspire the students' values, and enhance the students' theoretical elements. Raise. Teachers such as Wen Xiaoping, LiuYang and Zhang Quanxiang advocate the use of educational narrative in Ideological and political education.

\section{Text Narration in Ideological and Political Education}

We should pay attention to the excavation, interpretation and construction of texts. Ideological and political education text narrative can be as large as a book, as small as an article, or even a sentence and a loud slogan. The way of narration can be carried out by organizing study meetings and special lectures to form the study, study and education of texts.

\section{Image Narration in Ideological and Political Education}

Do image recognition, processing and enhancement. Not all images are suitable for carrying out ideological and political education narration. It is necessary to strengthen the ideological and political education subject construction of image processing to avoid indulging in the sensory enjoyment of "just looking at the picture". In addition, images can be arranged according to narrative logic, so that the narrative image is not only "beautiful" but also "active" and "distinct theme" to enhance the effect of image narrative.

\section{Social Memory Narrative in Ideological and Political Education}

Social memory refers to the process of encoding, storing and re-extracting all material and spiritual wealth created in productive practice and social life in the form of information. It opens the door of memory and provides the field of memory for the construction of Ideological and political education narrative. To cope with the development of the times, in the face of memory dilution, memory identity deficiency and narrative aesthetic fatigue, we need to pay more attention to enhance the ideological and political education narrative of the times. To grasp the epochal nature, we need to attach importance to the basic common sense that the memory of personal experience is the most lasting and resonant. We should use the social memory of teachers and students to construct the narrative of Ideological and political education.

\section{Construction of Narrative Teaching Method in Ideological and Political Theory Course}

Implementation Principles of Narrative Teaching Methods in Ideological and Political Theory Course

\section{The principle of story telling}

Narration, through plot, background and representation, makes a theme event have structure, context and meaning, and becomes the elements of the story. The narrative of Ideological and political education has "plot" and "readability". In the process of implementing education and teaching, educators should adhere to an objective and fair attitude and conduct effective teaching. Educators enlighten educational objects to express different views based on the points discussed. Educational objects unconsciously accept the values conveyed by ideological and political education in the "conflict" between them. The object of education constructs a new mode of thinking in the debate. 


\section{Practical principles}

Practice is the support way of narrative development in Ideological and political education. Every link in the narrative process of Ideological and political education is carried out in the practical activities of both the narrator and the information receiver. Narrator's "speaking" is the guarantee for the success of Ideological and political education. Through the dialogue between the educator and the object of education, the moral connotation and values implied in the story are clarified, and the moral knowledge is formed and transformed into practical behavior.

\section{Inquiry principle}

The narrative effect of Ideological and political education is closely related to whether or not to follow the inquiry principle. Inquiry is generally achieved through evaluation and evaluation.

\section{Reflective principles}

Knowledge convection and emotional convection are two main lines of interaction and mutual influence existing in the narrative teaching process of Ideological and political education. It affects the completion of teaching process. Reflection integrates knowledge cognition and emotional identity. The narration of Ideological and political education follows the principle of introspection. Reflect on normalization and form an atmosphere of coordination, education, trust and cooperation.

From education preparation, process implementation to activity summary, step by step. With the help of the story environment, the "teaching" of one-way thinking and the "thinking" of thinking communication link are integrated in the teaching process. On the premise of defining the focus of discussion, the true confession of the educational object is aroused by the way of story, so that the educator and the educational object can understand each other and reach a resonance on the key issues.

\section{The Realization Path of Narrative Teaching Method in Ideological and Political Theory Course}

A. What is Narrated: not Divorced from Theoretical System, Teaching Material System, and Teaching System.

"Narration" does not deny the charm of theory, but reproduces this charm from the logic of induction and deduction through practical knowledge narration. Narration is not a "storytelling" or a "chat room". It can not deviate from the true narrative. It seems lively on the surface, but in fact, it can not achieve the teaching purpose of Ideological and political lessons.

B. Who is Narrating: Giving Play to the Initiative of Teachers and Students in Two Aspects

1) play the leading role of teachers and infect students with the charm of teachers.

2) respect students' subjective status. Only by realizing participatory teaching and letting students seek what they have in their study can they change from "want me to learn" to "want me to learn".

\section{Narrating Text, Image and Memory: Realizing the Transformation from Teaching} Material System to Teaching System

1) The narrative text includes authoritative textbooks, including the teacher's own teaching plans, as well as stories and case sets.

2) Narrative images include video materials, oil paintings, sculptures, architecture, pictures, murals, as well as student works. Students have a sense of what they have learned to create works of art.

3) Narrative memory includes historical memory, red memory, revolutionary memory, as well as the memory of teachers and students themselves, using their own stories to infect the students around them.

\section{How to Narrate: Using Various Teaching Methods to Narrate}

1) the activation method of narration. The combination of ideology and politics is like the form of Ideological and political works of art. The combination of Ideological and medical care and humanistic care. Make full use of mobile learning systems such as Blue Cloud Class to use micro-video, images and other teaching, to achieve vivid image narrative. Let the narrative method be more characteristic of the times. 
2) the narrative language of life. Narration is humorous rather than dull. If the teacher can narrate through vivid stories, beautiful dialects, melodious tone and rich body language, classroom teaching will become relaxed, students will feel like a spring breeze in the process of learning.

How to realize the transformation of Ideological and political course from textbook system to teaching system and from teaching system to belief system after the implementation of the "05 program" of Ideological and political theory course in universities has been our concern. In practice, we use the theory and method of educational narrative research to construct a narrative teaching method in Ideological and political education. This improves the social identity of the narrative of Ideological and political education and realizes the speech of the political and ideological society. At the same time, it mobilizes the enthusiasm and initiative of students, and enhances the pertinence and effectiveness of classroom teaching. It makes students accept Marxism rationally, identify with it emotionally and practice Marxism in action, and achieves good teaching results. The following table is a survey on the effect of narrative teaching method in practical teaching. 589 valid questionnaires were collected from the students. The statistical results are as follows:

\begin{tabular}{|c|c|c|c|}
\hline Seaching types & Like & Commonly & Do not like \\
\hline Narrative text & $68.4 \%$ & $28.5 \%$ & $3.1 \%$ \\
\hline Narrative image & $78.8 \%$ & $18.6 \%$ & $2.6 \%$ \\
\hline Narrative memory & $78.6 \%$ & $14.5 \%$ & $6.9 \%$ \\
\hline
\end{tabular}

To construct the basic framework and logical system of narrative research in Ideological and political theory course as the academic support of this teaching method. At the same time, we also introduce the narrative ideas and methods into the ideological and political teaching, and further refine and concrete, in order to enhance the operability of this method. This paper studies the realization of micro-video function of Ideological and political education mobile learning system, and uses mobile learning system to realize the combination of text narrative and image narrative. Narrative teaching method is not only the theoretical summary of teaching experience, but also can be popularized and applied in teaching practice to achieve the unity of "metaphysical" theoretical construction and "line" specific operation.

\section{Acknowledgements}

This paper is funded by the special project of Ideological and political theory course education reform of Xi'an Peihua University in 2018. The project title: Text, Image and Memory: Research on the construction of narrative teaching method of Ideological and Political Theory Course.

\section{References}

[1] Wang Qiang. [J] Introduction to Ideological and Theoretical Education, 2009 (10)

[2] Long Diyong. Space Narratology [M]. Beijing: Life - Reading • New Knowledge Triple Bookstore, 2015

[3] Hao Lixin. Innovation in Marxist Theory Education from the Perspective of Times Issues [N] Guangming Daily, 2015-07-18 (7).

[4] Issued by the general office of the CPC Central Committee and the general office of the State Council.China's excellent traditional culture inheritance and development project[N]. People's daily, 2017-01-26(6)

[5] Croce. Theory and practice of history [M]. Fu Rengan,Translation: Beijing: Commercial Press, 1982:2. 